\title{
The Application of Interactive Teaching Method on College English
} Teaching Peng Chen ${ }^{1, a}$

\author{
${ }^{1}$ School of Foreign Languages, Nanyang Institute of Technology, Nanyang, Henan Province, \\ 473000 \\ ${ }^{\text {a }}$ email
}

Keywords: College English Teaching, Interactive Teaching Method, Application Research

\begin{abstract}
Interactive teaching method is based on modern teaching thinking and teaching theory as a guide, fully embodies the teacher-oriented, student as the main body, to training as the main line to thinking as the core of a new teaching model. College English traditional "one speech, spoon" and other teaching methods have lagged behind the needs of curriculum teaching, behind the development of modern education and the needs of student development. The application of interactive teaching method in college English teaching can fundamentally promote the teaching reform of college English.
\end{abstract}

\section{Introduction}

Modern teaching theory pointed out that the teaching process is a teacher-student interaction, positive interaction and common development process. The teaching of college English (non English majors) in our country has always been taught in the classroom. Teachers are the authority in the classroom to dominate everything, control everything and deal with all the events. This one-way single, teacher-dominated classroom so that students can not feel the joy of intellectual labor, alienated the students learning motivation, devoid of the students learning initiative, imprisoned and suffocated the students' creativity and imagination. Because of the lack of opportunities for students to participate, the lack of student experience in the world makes the "knowledge" to stay in the external, sluggish, lazy level. At the same time, through years of teaching college English this course, the author deeply realized that this one-way single teacher for the center of the lectures of teaching methods seriously affect the enthusiasm of teachers, teaching effect is often less effective. Therefore, we must constantly update the teaching concept, and constantly improve the teaching methods, pay attention to cultivating students' creative thinking, to maximize the potential of each student. Learning is an autonomous process, learners' creative thinking and positive cognitive participation are the most active factors in the learning process. It is futile to try to dictate what students must learn. The purpose of teaching should be to create conducive to learning the environment and conditions. At the same time, to improve the language perception of learners, so that they observe, analyze, reflect the language, both to help the language of the system, but also to develop their observation problems, the ability to analyze the problem, not only learn the language, but also learned how to learn The Classroom should not be a monopoly of teachers and students passive listening to the place, but should be teachers and students to communicate, dialogue, communication, inquiry learning interactive stage. In order to get rid of the traditional teaching methods, to teachers and students to create an interactive platform for teaching and learning, the author in the college English intensive course teaching exploratory application of interactive teaching method.

\section{The Principle of Interactive Teaching Method}

The so-called interactive teaching, that is, teaching and learning in teaching and learning in the process of communication, communication, consultation and discussion are equal to each other, listen to each other, accept each other on the basis of frankness, through rational persuasion and even debate to achieve different views collision, Stimulate the initiative of both sides of teaching, 
expand creative thinking, in order to improve the teaching effect of a teaching method. Interactive teaching and traditional teaching compared to the biggest difference lies in a word: "move". Traditional teaching is the teacher initiative, brain movement, mouth move, manual, the results of students passive, quiet, quiet mouth, quiet, and thus evolved into indoctrination, a speech. And interactive teaching fundamentally changed the situation, really "interactive", teachers take the initiative and students take the initiative to each other alternately, two-way input, more words, "I hit you pass, you hit me through" Movement. From the pedagogy, psychology point of view, interactive teaching has two major advantages: First, play a dual active role. Teachers and students are two-way communication, or answer doubts, or distinguish between right and wrong, on the one hand teachers activate the students of independent thinking ability, innovation or adaptability, on the other hand teachers should be fully prepared and keen thinking to accept the students The Second, to promote the level of double impact. Traditional teaching only stresses the influence of teachers, while ignoring the students should have the influence. And interactive teaching is to teach and learn both sides of the same theme of different ways of consultation and equal discussion, teachers in the eyes of students, respect for the independent views of students and solve the problem of analysis of the ability to communicate with students in the formation of spiritual collision and integration, to achieve the concept Of convergence. Therefore, the interactive teaching teachers to respect the psychological needs of students, listen to their thoughts on the problem, find its flash point, the formation of a common participation, common thinking, work together to solve the problem, the real psychological resonance, Sharing, the goal of the same, the impact of a total of dual effects to promote the double effect.

\section{The Change of the Role of Teachers and Students in the Interactive Teaching Mode}

After the realization of multimedia and network teaching, the role of teachers has changed. In the past in the traditional classroom, the teacher mainly in the classroom on the blackboard to teach, and now teachers not only to lectures, but also the curriculum designer, he designed the course, a certain stage of learning or learning of a student Curriculum content and the development of syllabus, the design of learning tasks, the provision of teaching materials, in the teaching process to demonstrate or play the role of consultants, while teachers control the teaching process and progress in the study more difficult Students, teachers can continue to encourage, but also to assess the results of teaching, teaching effects can also continue to conduct research. So the teacher's function is changed from the past to the instructor, who now becomes the designer of the course, the controller of the course progress, and the evaluator of the teaching achievement and the researcher of the teaching effect. Students become active explorers of knowledge, active practitioners of skills, participants in the teaching process, learners who overcome problems in the course of learning, or in the learning process.

In the multimedia environment, modern foreign language teaching methods to practice and use, teachers no longer dominate the classroom, no longer instill knowledge to students, but to promote and help students consciously learn. Students are flexible based on their own interests and abilities. Curiosity, learning interest and other learning motivation factors are enhanced, learning to become a student conscious behavior.

Multimedia technology provides a wealth of resources and convenient learning environment, so that the majority of the content previously explained by the teacher can be completed by students in the extracurricular. It makes teachers have more time and energy to implement the teaching of communicative approach. There are two ways of communicating online and face to face.

With the level of foreign language, the Internet and the improvement of the level of application of modern information technology, students can access to a more realistic foreign language environment, which has the same rich information resources with teachers.

In the multimedia environment, teachers are freed from the heavy classroom lectures, putting more time and energy into understanding the students' learning goals, learning styles and learning ability. To provide the first step in the teaching plan, teaching content and personalized teaching to provide first-hand information. So students become the focus of attention of teachers. It learns 
situation, personality characteristics of teaching orientation and road signs. Teachers from the stage before the scenes, to help students solve the learning process of language, cultural difficulties. The teaching is from "indoctrination" to research-oriented change. Students become the main body of teaching, teaching activities center.

\section{The Application of Interactive Teaching Method in College English Teaching}

The key to interactive teaching is to break the old-fashioned and boring of traditional English teaching. It emphasizes the bi-directional, interactive, communicative and emotional nature of the language learning process, emphasizing both the process and the results, so that students through positive thinking and behavior, To achieve the purpose of learning the language and the use of language. Interest is the best teacher, student learning interest is the core factor to play consciousness and enthusiasm. For high school students, the uneven level of English, easy to make students have different learning English mood, students have passed four or six examinations tend to despise the further study of English, poor English basic students are lack of learning Confidence, to bring a greater impact on English teaching. Teachers should guide students to understand the necessity and importance of English to start, and actively improve the teaching methods and means to gradually improve the students' interest in learning, which is the implementation of interactive teaching method of driving force.

By the infusion of thinking, college English teaching is often used in the traditional full-style irrigation, the students are teachers "holding away", lack of communication with each other, students thinking is not active, understanding is not thorough, tired and tired of learning, teaching effect can be thought And know. The introduction of interactive teaching method, bold teaching methods and means of reform and innovation, is conducive to play the students' initiative and participation in the sense of participation, is conducive to the creation of student-centered teaching atmosphere, is conducive to quality education convergence, in line with the development of the times demand.

Actively advocate in teachers and students, students and students to carry out a wide range of English-based multi-form, multi-occasion, multi-channel exchange activities, in order to create a local English "field" to further promote interactive teaching. College English teachers should strive to teach in the UK, the greatest possible rendering of the atmosphere of learning English. In addition, you can also use the actual English to carry out some small English lectures, small discussions and other language practice activities, to stimulate students to participate in the sense of participation and enthusiasm.

To strive for the diversity of classroom forms, highlighting the student's dominant position. The use of classroom discussions, debates, students try to teach, seminars and papers and other classroom forms, will be questions, dialogue, discussion, communication and other teaching methods, teachers take the lead in speaking English, encourage students to speak more English. Through the necessary design of the whole process of teaching planning, set the main points of teaching and communication, set up, create or simulate some scenes mood, design some classroom games, combined with the students' expertise, hobbies, life to explain the actual. Through the visualization, diversification of teaching, from top to bottom linkage, students' interest in learning is fully mobilized, so that students in a relaxed and pleasant atmosphere in the purpose of using language.

The use of the task class, each class are made clear tasks and requirements, so that students experience the joy of success in the interaction, while the success of the experience, to further stimulate the desire to interact.

To achieve a few changes: from the explanation to the inspiration to induce the change; from simply imparting knowledge to guide students how to obtain knowledge change; by imparting only the knowledge of books to improve the practical application of students to change; Learning "to" teach "," learn "interactive change.

Open up a colorful second class, entertaining, and further reinforce the classroom teaching. Such as English speech contest, English group debate contest, English original article translation contest, 
English reading contest, simulation academic conference discussion, etc., these extracurricular practice activities are classroom teaching supplement, Is conducive to cultivating students' comprehensive quality and innovation ability.

\section{Acknowledgements}

This article is the 20th century, Nanyang City, Henan, soft science research project "application-oriented college students in English speculative ability training" stage results.

Project number: RKX13.

\section{References}

[1] Li Zongshun. Application of Multimedia Interactive Teaching Model in English Teaching [J]. China Press, 2012, (08)

[2] Liu Xiao, Wu Zhongjie. Network-based interactive writing and review mode exploration [J]. Overseas English, 2012, (03)

[3] Shaoyang, Xiu Fengying. Study on College English Interactive Teaching Model Based on Network Environment [J]. Journal of Nanchang College of Education, 2011, (11)

[4] Liu Yumei. Interactive teaching in English teaching application [J]. Reading and writing, 2011, (06)

[5] Fan Jia. English and Chinese discourse differences on Chinese college English writing teaching enlightenment [J]. Overseas English, 2011, (02) 